\title{
Climate Change and the Surge for Pandemics
}

\author{
Durr e Shehvaar $^{1}$, Wardah Idris $^{1} \&$ Mubashira Ahmed ${ }^{1}$ \\ ${ }^{1}$ Department of Political science and International Relations, University of Management and Technology, Lahore, \\ Pakistan \\ Corresponding Author (Principal Author): Durr e Shehvaar, Department of Political science and International \\ Relations, University of Management and Technology, Lahore, Pakistan. E-mail: F2018188062@umt.edu.pk
}

Received: April 20, 2020

doi:10.5539/jsd.v13n3p138
Accepted: May 28, $2020 \quad$ Online Published: May 30, 2020

URL: https://doi.org/10.5539/jsd.v13n3p138

\begin{abstract}
The pandemic of the century has caused great concern about the global environmental crisis. The article outlines the various aspects of the surge of pandemic its link to climate change along with the prospects for the nation-states and how they have seen it as a challenge as it is being seen as taking thousands of lives. In the literature review, the research problem that has been tailored is if the pandemic can create a common awareness about the global climate crisis that has destructive projections for the globe itself. A causal link between the surge of pandemics and climate change that helps spread the viruses has been created. In addition to this, we further argue that the nation-states and their exploitative corporate goals that are manipulating the environment should be curbed through decisive steps.
\end{abstract}

Keywords: Climate Change, Environmental Crisis, Nation-states, Pandemic

\section{Introduction}

Pandemics, we all know, have caused a large number of deaths on an international level throughout the years in the form of plague, influenza, cholera, etc. They have changed the history of the world (Lei Xu, et al.2010). It is observed recently that changes that occurred in the climate and atmosphere of the earth are due to the callous role of human beings, which has a great impact on numerous health results. This may include modified proportions of many types of contagious diseases (Mcmichael \& Lindgren, 2011a). Invulnerable countries, climate change is worsening health outcomes. It will influence the development of contagious diseases, affect food yield and nutrition, raise the likelihood of climate-related disasters, and damage mental health (Mcmichael \& Lindgren, 2011b).

The life on the earth i.e. human and wildlife have been threatened by numerous diseases that are emerging at an alarming rate and rising environmental chaos and ecosystem risks to human health. There are some global factors like climate change that contributes to the emergence of diseases (Liu et al., 2013). Biodiversity could be highly affected by climate change and the organisms which are influenced by the changing of the environment can be highly sensitive to the carriers of diseases (Bradley et al., 2005).

Most climate scientists around the world believe that emissions from human activities into the lower atmosphere of $\mathrm{CO} 2$, chlorofluorocarbons, and other greenhouse gases now contribute greatly to the continuing temperature increasing of the Earth's surface. This human activity is causing swear disaster and is one of the biggest factors for global climate change (Mcmichael \& Lindgren, 2011c).

The increase in temperature due to global warming is becoming the cause of flooding and an increase in heavy rainfall etc. Various incidents that followed flooding have been recorded which led to contamination of underground drinking water sources. Heavy rainfall also contributes to the degradation of surface water quality, which may adversely affect the health of those engaging in recreational contact with water. There is some kind of harmful bacteria and viruses in the water that may cause severe diseases on drinking i.e. cyanobacteria. Although heightened temperatures may lead to favorable climatic conditions in some vector-borne diseases such as malaria. And when the disease spreads it can become a cause for a pandemic (Hunter, 2003).

The COVID-19 pandemic is now terrorizing the world and it has shown that we are not scientifically mature and trained as we thought we were compared to a hundred years ago. Climate change is to blame for the spread of this disease and in the future, if we fail to address climate change, virus outbreaks will become more frequent (Zhang et al.,2020). 
Now President Trump being the protagonist of the offensive realism believing in the opportunistic state power maximization to continue the legacy of dominating the international system has taken a strong confident path. In times of crisis, no powerful nation tends to pose itself as vulnerable and weak and so is China, Russia, and the US was seen to be doing. While Europe is seen to be the fourth player in world politics with French president Emmanuel Macron visioning a sovereign Europe. Before the pandemic, Russia moved against the US and Saudi oil business and is now seems to have its economy extremely tested by plunging oil prices. China too has its all export business shut down to a large extent with the US to have its market get crashed due to lockdowns. Moreover, we know it's a year of the presidential elections so pandemic causing the economic threshold will act negatively political (Ehlers, 2020).

Carrying this context and the importance of this problem in mind, it is very important to research the origins and consequences of the pandemics. The seriousness of this issue, which has eclipsed all the big issues of today's world, required to be keenly observed. Since this topic does not contain enough literature review and does not have enough articles for the study we choose this topic to compile a literature review and make a valuable and good research article about this topic.

The objective to study this topic is containing more data about the consequences and drawbacks of pandemic and how can we reduce the surge of it. Further in this paper, the literature review will contain the awareness about the climate crisis on a global level and what measures should be taken in the situation of a pandemic. In this literature review, an investigation of the link between the climate crisis and how it has progressed diseases that can potentially turn into pandemics, later on, will also be involved. Furthermore, this research paper will also list possible solutions to control current defects caused by climate change

\section{The Climate Crisis}

Everything in the universe is in balance. From the sun rising to the moon in perfect alignment to the earth. One shift in these paradigms can cause celestial catastrophes. The same pattern applies to earth as well. Our fauna and flora are the earth's guardian angel and the vital source of human nourishment and enrichment. The human's lack of understanding of mute things is their biggest ignorance and destroying those things will be the end of life to all lives.

A shift in the global temperature can give rise to major catastrophes. The temperature has risen globally by $0.6^{\circ} \mathrm{C}$ and the effects are observed globally. If the temperature continues to rise by $1-5^{\circ} \mathrm{C}$ globally then the world can experience loss of agriculture yield, water scarcity, forest fires (especially rainforests that produce $20 \%$ of the planet's oxygen), flood, hunger, increase in diseases such as malaria and dengue and melting of ice sheets in Antarctica which would give rise to extreme temperatures (Schellnhuber, et al, 2006).

Not only will this have disastrous results on the ecosystem but also the human lifestyle and the country. There will be regional damages especially for developing nations and the toll of catastrophes on human life. Deforestation is increasing the risks of fruit bats and mosquitos thus increasing the spread of malaria. For every $10 \%$ increase in deforestation, there has been a $3.27 \%$ increase in malaria cases which means 10,000 cases per year (X, Kong,2017). If diseases continue to raise this will paralyze the local economy as well as a daily human activity.

Just as humans are evolving medicines to enhance our immune system so are bacteria and viruses. New emerging bacteria are resistant to antibiotics. There are currently many plagues and diseases frozen in ice but due to the climate crisis, there is the fear of awakening these diseases. One example persists of the Yamal Peninsula located in the Arctic Circle where there have been new cases of people and animals being infected with anthrax (Fox-Skelly, 2017). When the earth will warm, the permafrost will melt and the dormant bacteria will be active again, wreaking havoc on the human lives and ecosystem.

Clean air is the biggest resource for human survival. A slight adulteration in that and we would cease to live. Since everyone is in a hurry these days and everyone owns a mode of transport that uses fuel the air is filled with pollutants. The air we are currently breathings has been filled with pollutants that will show its impacts on our health in the long run. Cities are the major polluters and are causing distress in everyone's lives. Living near high-traffic roads can increase asthma by $15 \%$ and other chronic diseases (Roces, 2020). Air pollution kills over 7 million people per year around the globe. There is a link that people living in high pollutant areas are susceptible to COVID-19. (Campbell-Lendrum.2020). Although, COVID-19 isn't a direct influence of climate change it doesn't derail from the fact that climate change can help spread future diseases.

Changing weather patterns will increase vectors and spread diseases. Heavily polluting industries such as fossil fuel and factory farming are the main culprits of climate change and contributors to disease transmission. Factory 
farming is linked to methane emissions which are progressing faster-mutating and more dangerous pathogens. These corporate institutions are already the malefactors of destroying the planet and exacerbating the evolution of creating deadlier diseases, more quickly, in an unstable, vulnerable world.

Human life, as usual, will receive the boot-end on their health and economic effect due to corporate greed.

\section{Pandemics and Climate Crisis: The Contemporary Situation}

As of April 2020, the COVID-19 pandemic is ravaging the planet and it has proved that we are not medically advanced and prepared as we thought we were compared to hundred years ago. In a matter of weeks, society and the social order has been transformed. There are shortages of ventilators and masks as bodies pile up day by day and a vaccine is nowhere in sight. The spread of this disease is to be blamed for climate change and in the future, viral outbreaks will become more common if we refuse to tackle climate change.

The COVID-19 virus can spread through droplets and no one is immune to this virus. It takes five-seven days for symptoms to appear however by then the infected individual would've infected many others. Even though it has been proven that the COVID-19 is not seasonal flu, like most viruses with non-seasonal flu characteristics, it doesn't dissolve the argument that climate change is exacerbating the influence and surge of diseases. "Climate change is a threat multiplier, something that exacerbates existing problems and creates new ones. No aspect of life on this planet has been untouched by climate change - viruses included" (Kaplan,2020). Around 320,000 recorded viruses can affect one mammal. However, most of them rarely stick.

\subsection{Causal Relation between Changed Disease Pattern and Climate Change}

A virus needs to evolve for it to infect the masses such as measles virus that has been around since the third Century. Due to habitat disruption, most animal population shrink which affects their biodiversity - depriving them of useful survival genes needed to adapt under extreme conditions. Global warming is causing a major migration of habitats, making them travel away from the equator and move to higher altitudes which will expose them to new diseases that they are not immune to. Due to long migration, it causes stress on particular animals, weakening their immune systems and in turn being more prone to infections and diseases. The climate crisis will cause migration of animals to move closer to humans and expose them to new diseases that both ecosystems are unprepared for. World Health Organization summarizes the link of disease spreading as follows:

1) Insect vectors

2) Animal hosts

3) Human contact

4) The immune system

"Changes in infectious disease transmission patterns are a likely major consequence of climate change. We need to learn more about the underlying complex causal relationships and apply this information to the prediction of future impacts, using more complete, better validated, integrated, models" (WHO,2020). Climate change weakens vector ecology and during a crisis it exacerbates that liability by affecting human lives through increase in disease outbreaks, differentiation in $\mathrm{pH}$ levels which would affect soil and other ecosystem services such as food and water supply, soil formation and nutrients, etc. This would cause a reaction in animal migration that will fight for their survival. It is estimated that by 2025, nearly a quarter of the Earth's population would suffer from water scarcity due to monsoon seasons and extreme heat waves. Most countries that are facing water stress are using most of the surface groundwater in an average year which is bound to excel climate change consequences (Dormido, 2019)

Climate change can also affect sensitivity if our health is compromised especially in regions of water and food scarcity. These conditions make us susceptible to infectious diseases.

Pandemic outbreak where human-human interactions in vector-borne regions are high, such as urban areas, then the mortality and impact rate would be severe.

Pandemics, like the COVID-19, are bound to occur more often if the climate crisis remains unabated. Pandemics have proven to be stronger than wars itself especially since a microscopic entity has stirred such panic and caution and has halted the human day-to-day life till the unknown future. Pandemics have proven to be stronger than wars itself especially since a microscopic entity has stirred such panic and caution and has halted the human day-to-day life till the unknown future.

\section{Global Environmental Crisis and Its Prospects for the Global Order}

The pandemic of the century has been seen making its way throughout the world due to which it seems that no 
society or the economy is immune (Walsh, 2020). Stark effects are predicted to impact the global economy. In all this, an important dimension is being overlooked which is an important element to this insidious virus -the geopolitical element. COVID-19 is rapidly unfolding the treat tendencies to international relations. One certain thing that is being assured is the continuation of the great power rivalry (Shah \& Akhtar, 2018a).

It follows that the international order has to go through some serious test of time as the global economies have shrunk to a large extent already. Before this pandemic of the century, theorists used to refer back to the $1920 \mathrm{~s}$ and 1930s, global recessions, and great depression periods and witness the massive unemployment and unwelcomed economic hardships. Thus, today too, the domestic polities seem to witness the same disturbances and fatalities (Shah \& Akhtar, 2018b).

Before the pandemic, Russia moved against the US and Saudi oil business and is now seemed to have its economy extremely tested by plunging oil prices. China too has its all export business shut down to a large extent with the US to have its market get crashed due to lockdowns. Moreover, we know it's a year of the presidential elections so pandemic causing the economic threshold will act negatively political (Biermann, Frank \& Ding Werth, Klaus, 2004).

Regardless of the terrible idea of the pandemic of the century, the round of extraordinary force contention will proceed unabated. Undoubtedly, sometimes, the turmoil may give an interruption, empowering further activity, and subterfuge. This is a fortunate time to evaluate the capacity of how a state assimilates, and bounce back from, a universal emergency (Oosthoek \& Gills, 2005). The incredible forces will keep on taking each other's measure. China, US, and worldwide banners with business sectors smashing, and organizations confronting extraordinary difficulties all-inclusive, there's an undeniable probability of expanding joblessness rates in work advertised effectively under pressure. Also, in legislative issues, particularly in a political decision year, occupations and employment creation are consistently the intensely hot issue. For the time being, in any event, things will be extreme. All through the COVID-19 emergency, anyway long it should last, it is well to recall that during the 1920s, one-party rule flourished in war-attacked European countries. After World War I, businesses were attempting to financially recover, and populaces endeavored to manufacture new lives. The destructive move in the more extensive economy during the Great Depression catalyzed ultra-patriotism and conservative radicalism, at last prompting World War II (Walsh, BBC, 2020).

To be clear, the real war the world faces today is the one against COVID-19. This pandemic will have political ramifications one cannot yet see or imagine. This is why it's vital to be aware of how the confluence of a depressed global economy, as a result of an unprecedented crisis, coupled with heightened nationalism and heated political rhetoric, can unleash negative politics with dire outcomes - within countries, and between them. It's imperative that world leaders heed the lessons of the past (Rubin, 2011).

\section{How to Prevent the Climate Crisis}

A Green New Deal has been in the talks for years now. This deal will finalize the initiatives that need to be taken to solve the climate crisis whilst tackling the socio-economic impacts and each and every country needs to be on board when that happens. It talks about universal healthcare, national transport system, infrastructure, and much more that might be contributing to the crisis.

The first step to tackle climate change is through mitigation and adaptation. We need to reduce greenhouse gasses emission and adapt to the current climate to plan ahead and prevent things from getting disastrous. We must create deals that benefit our health and environment with regard to the socio-economic impacts of it as well. Our health should be our top priority.

We need to raise our voice to force the state to create and make deals that will protect the planet such as the Paris Agreement where 197 countries signed on this deal to take an approach towards tackling climate change and reduce their carbon footprint. Reduce one's carbon footprint meaning using things less of that emits carbon dioxide. This includes owning a car, frequently traveling by airplanes, etc. Reduce the intake of meat. It takes $5,000-20,000$ liters of water to produce $1 \mathrm{~kg}$ of beef (Smithers, 2013).

Investing in renewable energy like solar energy and electric cars, trains, etc. Making renewable and reusable resources such as replacing plastic with tartar baskets, reusable cloth bags, etc. Getting rid of fast fashion and finding a sustainable way to shop. Currently, the fast fashion industry contributes $8 \%$ of carbon dioxide to the earth, making it one of the climate culprits (Cerullo, 2019).

Getting rid of systems where only the people on the top are benefitting from. The disparity between classes is a major factor in contributing to global warming. Corporate greed and interest will beseech all boundaries to maximize their profit even if it comes at the expense of putting the planet at risk a global approach to tackling 
climate change. Without a collaborative effort, tackling this crisis would be futile.

\section{References}

Ahamer, G. (2012). Regeln von "Surfing Global Change": ein didaktischer Baustein (in German).

al, S. e. (2006-02-02). Avoiding Dangerous Climate Change.

Bradley, M. J., Kutz, S. J., Jenkins, E., \& O'Hara, T. M. (2005). The potential impact of climate change on infectious diseases of Arctic fauna. International Journal of Circumpolar Health, 64(5), 468-477. https://doi.org/10.3402/ijch.v64i5.18028

Dietz, W. H. (2020). Climate change and malnutrition: we need to act now. The Journal of Clinical Investigation, 130(2). https://doi.org/10.1172/JCI135004

Dormido, H. (2019, August 6). These Countries Are the Most at Risk From a Water Crisis. Retrieved from https://www.bloomberg.com/graphics/2019-countries-facing-water-crisis

Estrada, e. a. (n.d.). Pandemics in a changing climate - Evolving risk and the global response. Retrieved from https://www.swissre.com/dam/jcr:552d59b2-76c6-4626-a91a-75b0ed58927e/Pandemics_in_a_changing_cli mate_Full_report_FINAL.pdf

Fox-Skelly, J. (2017, May 4). There are diseases hidden in ice, and they are waking up. Retrieved from $\mathrm{http} / / / w w w . b b c . c o m / e a r t h / s t o r y / 20170504-t_{h}$ re-are-diseases-hidden-in-ice-and-they-are-waking-up

Galea, D. S. (2019, March 4). The Case for a 'Health New Deal'. Retrieved from https://fortune.com/2019/03/04/health-new-deal

Gunn-Wright, R. (2020, April 15). Think This Pandemic Is Bad? We Have Another Crisis Coming. Retrieved from https://www.nytimes.com/2020/04/15/opinion/climate-change-covid-economy.html

Hunter, P. (2003). Climate change and waterborne and vector-borne disease. Journal of Applied Microbiology, 94(s1), 37-46. https://doi.org/10.1046/j.1365-2672.94.s1.5.x

Kaplan, S. (2020, April 15). Climate change affects everything - even the coronavirus. Retrieved from https://www.washingtonpost.com/climate-solutions/2020/04/15/climate-change-affects-everything-even-cor onavirus/?arc404=true

Kavanagh, M. et al. (2019). Ending Pandemics: US Foreign Policy to Mitigate Today's Major Killers, Tomorrow's Outbreaks, and the Health Impacts of Climate Change. Journal of International Affairs.

Kingland, J. (2020, April 3). How might climate change affect the spread of viruses? Retrieved from https://www.medicalnewstoday.com/articles/how-might-global-warming-influence-the-spread-of-viruses\#A -taste-of-things-to-come

Liu, X., Rohr, J. R., \& Li, Y. (2013). Climate, vegetation, introduced hosts, and trade shape a global wildlife pandemic. Proceedings of the Royal Society B: Biological Sciences, 280(1753), 20122506. https://doi.org/10.1098/rspb.2012.2506

Mcmichael, A. J., \& Lindgren, E. (2011). Climate change: present and future risks to health, and necessary $\begin{array}{llll}\text { responses. Journal of Internal } & \text { Medicine, 270(5), }\end{array}$ https://doi.org/10.1111/j.1365-2796.2011.02415.x

Micklas, B. (2020, April 23). 5 Things to Know About Climate Change and Coronavirus with WHO Climate Lead Dr. Campbell-Lendrum. Retrieved https://www.ecowatch.com/5-things-climate-change-coronavirus-who-2645813454.html

Roces, M. (2020). Air Pollution: It's Time for a New Deal to Protect Health. International Journal of Environmental Research and Public Health, 1-2.

Vaughan, A. (2019, Oct 15). How deadly disease outbreaks could worsen as the climate changes. Retrieved from https://www.newscientist.com/article/2219981-how-deadly-disease-outbreaks-could-worsen-as-the-climatechanges/

WHO. (2020). Climate change and human health. Retrieved from https://www.who.int/globalchange/summary/en/index5.html

$\mathrm{Xu}$, L. et al. (2011). Nonlinear effect of climate on plague during the third pandemic in China. Proceedings of the National Academy of Sciences, 108(25), 10214-10219.

$\mathrm{Xu}$, L. et al. (2019). Historical and genomic data reveal the influencing factors on global transmission velocity of 
plague during the Third Pandemic. Proceedings of the National Academy of Sciences, 116(24), 1183311838. https://doi.org/10.1073/pnas.1019486108

Zhang, J. (2020, Feb 24). Coronavirus Response Shows the World Is Not Ready for Climate-Induced Pandemics. Retrieved from https://blogs.ei.columbia.edu/2020/02/24/coronavirus-climate-induced-pandemics/

\section{Copyrights}

Copyright for this article is retained by the author(s), with first publication rights granted to the journal.

This is an open-access article distributed under the terms and conditions of the Creative Commons Attribution license (http://creativecommons.org/licenses/by/4.0/). 